\title{
Metamorphosis in a semiterrestrial crab, Sesarma curacaoense: intra- and interspecific settlement cues from adult odors
}

\author{
P. Gebauer ${ }^{\mathrm{a}}$, K. Paschke ${ }^{\mathrm{a}}$, K. Anger ${ }^{\mathrm{b}, *}$ \\ ${ }^{a}$ Facultad de Pesquerías y Oceanografia, Universidad Austral de Chile, Casilla 1327, Puerto Montt, Chile \\ ${ }^{\mathrm{b}}$ Biologische Anstalt Helgoland, Stiftung Alfred-Wegener-Institut für Polar- und Meeresforschung, \\ 27498 Helgoland, Germany
}

Received 29 May 2001; received in revised form 3 August 2001; accepted 9 October 2001

\begin{abstract}
The larvae of many marine invertebrate species are able to delay their settlement and metamorphosis in the absence of characteristic cues from the adult habitat. This phenomenon was experimentally studied in the megalopa stage of Sesarma curacaoense de Man, 1892, a semiterrestrial grapsid crab that lives in the shallow coastal mangrove habitats in the Caribbean region. Duration of the development and survival to metamorphosis to the first juvenile crab stage were compared between experimental treatments, where the water was conditioned with adult crabs ("adult-conditioned water," ACW) and control groups reared in filtered seawater. In the experiments with larvae from two different females, development duration was significantly shorter and mortality lower in water conditioned with conspecific adults. In the two control groups, the effects of supply with an artificial substrate (nylon gauze) were tested. This comparison showed that the presence of substrate did not significantly influence the time to metamorphosis, but did reduce the mortality rate. In all later experiments, the megalopae were thus routinely provided with nylon gauze as a substrate. In each of the three subsequent replicate experiments conducted with larvae from different females, survival rate and development time to metamorphosis were compared between one control group and four treatments with ACW. The effectiveness of conspecific ( $S$. curacaoense) adult odors as metamorphosis-stimulating cue was, in these experiments, compared with that of ACW from one congener (S. rectum) and two species belonging to different genera within the Grapsidae (Armases miersii, Chasmagnathus granulata). While the rate of survival showed inconsistent patterns among repeated experiments, the development was consistently
\end{abstract}

\footnotetext{
* Corresponding author. Fax: +49-4725-819-369.

E-mail address: kanger@awi-bremorhaven.de (K. Anger).
} 
fastest with conspecific ACW, followed by ACW from S. rectum, A. miersii and C. granulata. Only the conspecific and congeneric cues had statistically significant effects (i.e. shorter development than in the controls). These response patterns suggest that chemically similar factors (presumably pheromones) are produced by closely related species and, thus, their chemical structure may reflect phylogenetical relationships within a clade. (C) 2002 Elsevier Science B.V. All rights reserved.

Keywords: Crab, Metamorphosis; Settlement cues; Grapsidae; Phylogenetic relationships; Sesarma, Armases; Chasmagnathus

\section{Introduction}

Larvae of numerous species of benthic marine invertebrates settle and metamorphose nonrandomly in habitats that are suitable for adult life. Their metamorphosis is triggered by physical and/or chemical cues associated with the adult habitat. The absence of such cues may cause a developmental delay of several hours to months (for review, see Pechenik, 1990). In general, this phenomenon is common among sessile forms such as barnacles and bryozoans, but less frequently documented in motile species. Among the decapod crustaceans, evidence of metamorphosis-stimulating cues has been shown, for instance, in various estuarine species such as the blue crab, Callinectes sapidus, where decreasing salinity, humic acids, odors from estuarine seagrasses, saltmarsh cordgrass, or macroalgae, and several other cues associated with water of riverine origin may indicate a suitable habitat for the settlement and recruitment to the adult population (Wolcott and de Vries, 1994; Forward et al., 1996, 1997a,b; Fitzgerald et al., 1998). In addition, the type of sediment which is a characteristic for the adult habitat has been demonstrated as a stimulating factor, e.g. in mud crabs, Panopeus herbstii (Weber and Epifanio, 1996), fiddler crabs, Uca pugilator, U. pugnax (Christy, 1989; O'Connor, 1991; O'Connor and Judge, 1997), and salt marsh crabs, Chasmagnathus granulata (Gebauer et al., 1998, 1999). Similarly, the presence or absence of empty snail shells affects the metamorphosis in some (although not all) hermit crab species (e.g. Harms, 1992; Harvey, 1996; Brodie, 1999).

Among the potential cues from the parental environment, odors released by conspecific adults should represent the most characteristic indication of a favourable habitat for postsettlement survival and growth. Stimulating effects of conspecific adult odors were demonstrated in competent megalopae of fiddler crabs, U. pugilator, U. pugnax (O'Connor, 1991; O’Connor and Gregg, 1998), mud crabs, P. herbstii (Weber and Epifanio, 1996), porcellain crabs, Petrolisthes spp. (Jensen, 1991), and several hermit crab species (Harvey, 1996). Recently, this was experimentally shown also in an estuarine grapsid crab, C. granulata (Gebauer et al., 1998, 1999).

In the present study, we investigated the metamorphic response of megalopae to adultconditioned water in another grapsid crab species, Sesarma curacaoense de Man, 1892, which lives in the shallow brackish mangrove swamps in the Caribbean region. Moreover, we tested the potentially confounding effects of substrate availability, and we compared the intraspecific response to odors from adult $S$. curacaoense with the effectiveness of 
odors from other grapsid crabs. One of these is a congener, S. rectum, while another species, Armases miersii (formerly $S$. miersii) has only recently been assigned to a new genus, Armases, which is considered closely related to Sesarma (Abele, 1992). Another species that we tested in this study, C. granulata, belongs, at present, also to the subfamily Sesarminae, but recent genetic and morphological evidence suggests that it is phylogenetically more distant from Sesarma and should be moved to the Varuninae (Schubart et al., 2000).

These species were selected because they allow various interesting comparisons and tests of working hypotheses. (1) They show differential taxonomical positions within the Grapsidae, i.e. different phylogenetic distance to $S$. curacaoense (see Schubart et al., 2000); if the effectiveness of adult odors is associated with the phylogenetic distance between the species in a clade, then the closest relative (in this case, the congener $S$. rectum) should have the strongest interspecific metamorphosis-stimulating effect. (2) It is also conceivable that the megalopae have evolved the capability to chemically recognize sympatric species, which co-occur in their natural habitat, but not allopatric species. In this case, only the sympatric species $A$. miersii should have a significant interspecific effect on the metamorphosis of $S$. curacaoense. (3) Among the species tested in this study, so far, only $C$. granulata has been shown to produce effective metamorphosis-stimulating chemical cues (Gebauer et al., 1998, 1999). If these substances were fairly unspecific, at least within the grapsid family, then odors from this species should have the strongest interspecific effect on metamorphosis in $S$. curacaoense megalopae.

\section{Materials and methods}

\subsection{Origin of materials, larval rearing}

Adult $S$. curacaoense and A. miersii were collected from brackish coastal mangrove (Rhizophora mangle, Avicennia germinans) swamps and from supratidal rock pools, respectively, in Jamaica (see Anger and Schultze, 1995), and transported alive to the Helgoland Marine Biological Station, Germany. Adult S. rectum were collected from a mangrove swamp near Bertioga (State of São Paulo, Brazil), C. granulata from the coastal lagoon of Mar Chiquita (Argentina; see Spivak et al., 1994). All these estuarine species (except $S$. rectum) have been cultivated in the laboratory at Helgoland through several successive generations, so that larvae and all other life-history stages have almost continually been available for experimental studies (for further details and references related to the origin, ecology, and cultivation of these species, see Anger, 1995, 1996; Gebauer et al., 1998, 1999; Anger and Charmantier, 2000).

Zoeae were of S. curacaoense, were mass-reared in 390-ml beakers (maximum 30 larvae per beaker), without aeration, constant $24{ }^{\circ} \mathrm{C}, 25 \%$ salinity, and a 12:12-h light/ dark cycle. The culture medium was changed daily, and the larvae were fed with freshly hatched Artemia franciscana nauplii at a density of approximately 10/ml. 


\subsection{Experiment 1: effects of artificial substrate and conspecific cues on metamorphosis}

Groups of 15 freshly moulted megalopae of $S$. curacaoense were randomly distributed among one experimental treatment with adult-conditioned water (ACW) and two controls with filtered seawater (in all cases $24{ }^{\circ} \mathrm{C}, 25 \%$ salinity). ACW-treated megalopae were placed in an aquarium with 21 of seawater $(25 \%$ o ), in which a sieve (300 $\mu \mathrm{m}$ mesh size) with a conspecific adult was immersed. Controls were treated identically but without adults in the aquaria; one control group was kept with, the other without, nylon gauze as an artificial substrate. This experiment was carried out twice, using hatches from two different females (\#\# 1, 2), with five and four replicates, respectively (due to different hatch size); hence, each set of experiments comprised 3 conditions $\times 4$ or 5 replicates $\times 15$ individuals, i.e. 180 and 225 megalopae, respectively, or 405 individuals in total. In this and all other experiments, molting and survival were noted daily.

\subsection{Experiment 2: effects of intra- and interspecific cues on metamorphosis}

In order to compare metamorphosis-stimulating effects of conspecific adults (intraspecific effects) with possible effects of odors from other Grapsidae (interspecific effects), 180 freshly moulted $S$. curacaoense megalopae larvae were divided among one control with filtered seawater and four experimental treatments with ACW, comprising three replicates with 12 individuals each. The megalopae were reared in bowls with $390 \mathrm{ml}$ water and pieces of nylon gauze given as a substrate; the temperature and salinity conditions were the same as in experiment 1 . ACW was, in this experiment, produced by keeping adult crabs (one individual each of $S$. curacaoense, $S$. rectum, A. miersii, $C$. granulata) in the 2-1 aquaria with water of $25 \%$ salinity. This water was used in the ACW treatments and replaced daily. This experiment was carried out three times, using megalopae originating from three different females (\#\# 3-5). Hence, each set of experiments (with larvae from one hatch) comprised 5 conditions $\times 3$ replicates $\times 12$ individuals, i.e. 180 megalopae each. With its three repetitions, this experiment, thus, comprised 540 megalopae in total.

\subsection{Statistical analyses}

Effects of different experimental conditions were primarily analysed comparing the rate of survival and the mean duration of the megalopa stage. In order to further analyse the frequency pattern of metamorphosis throughout an experiment, we compared additionally the percentage of metamorphoses on two separate days in each experiment. Percentage metamorphosis values were calculated in all experimental groups, (1) on the day when at least $50 \%$ of the larvae in the treatment with the fastest development had undergone metamorphosis; (2) again, on the day when at least $50 \%$ of the megalopae in all treatments had moulted to the first juvenile. This separation was made, because the effects of metamorphosis-stimulating cues may be underestimated if, exclusively, the second (more commonly used) time within the experimental period is considered. This 
may occur due to the spontaneous metamorphoses in the control group and, in a late phase of the experiment, also mortality plays an increasing role for the estimates of percentage metamorphosis.

All statistical analyses followed standard techniques (Sokal and Rohlf, 1995). Zero and $100 \%$ values were weighted as suggested by Snedecor and Cochran (1967, p. 327) for small sample size $(<50)$. All percentage values were arcsin and subsequently square root transformed for statistical analysis. When the data complied with the requirements for parametrical tests, one-way Analysis of variance (ANOVA) was used, otherwise, the non-parametrical (i.e. less powerful) Kruskal-Wallis $H$-test. Multiple comparisons were done with Student-Newman-Keuls, and comparisons with the control treatments using the Dunnett test. Independence $R \times C$ tests were used to analyse effects on larval mortality.
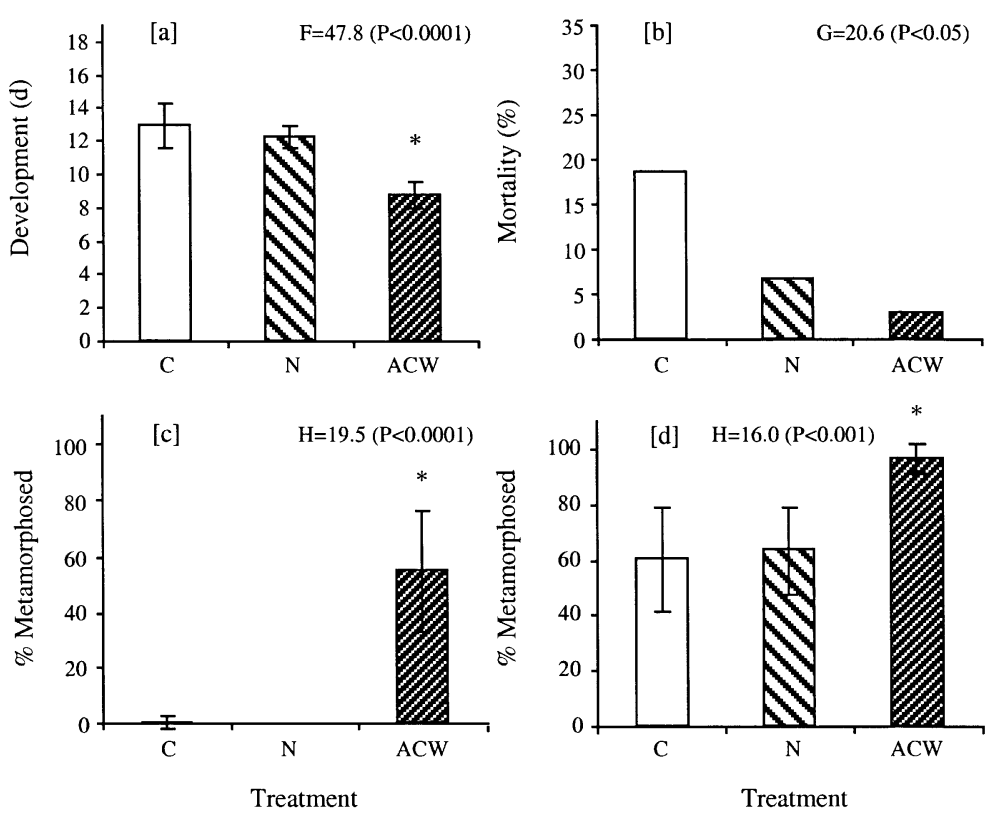

Fig. 1. Effects of substrate (nylon gauze) availability and conspecific (S. curacaoense) adult-conditioned water (ACW) on the development and survival of $S$. curacaoense megalopae (experiment 1; pooled data from females \#\# 1, 2). (a) Mean duration of megalopa development to metamorphosis (days, means \pm S.D.; range: $8-27$ days without substrate, 9-23 days with sieve, 7-14 days with ACW). (b) Mortality (\%). (c) Percentage of metamorphosed megalopae (means \pm S.D.) on the day when, in the treatment with the fastest development, at least $50 \%$ of the megalopae passed through metamorphosis (day 8). (d) Percentage of metamorphosed megalopae (means \pm S.D.) on the day when, in all treatments combined, at least $50 \%$ of the megalopae passed through metamorphosis (day 12). $H$ : Kruskal-Wallis statistic; $F: F$-statistic; $G$ : statistic of $G$-test for independence; $P$ : probability of error for rejecting the null hypothesis. * Significant difference $(P<0.05)$ based on multiple comparisons; pooled data of two females. C: control group (filtered seawater, not conditioned with adults), N: control condition but with nylon gauze given as a substrate. 


\section{Results}

\subsection{Effects of substrate availability and conspecific adult odors (experiment 1)}

The results obtained in experiment 1 with larvae from two different hatches (females \#\# $1,2)$ were pooled, since no significant differences ( $t$-tests) were found in the development duration or survival of the megalopae. The presence of nylon gauze as an artificial substrate, by contrast, reduced significantly the mortality as compared with the control lacking such a substrate ( $7 \%$ vs. $18.5 \%$; Fig. 1b). As a consequence of this observation, nylon gauze was in all further experiments routinely supplied as a substrate. The effects of substrate availability on the duration of the development and on the percentage of metamorphoses reached on two selected days of development, by contrast, were insignificant (Fig. 1a, c, d).
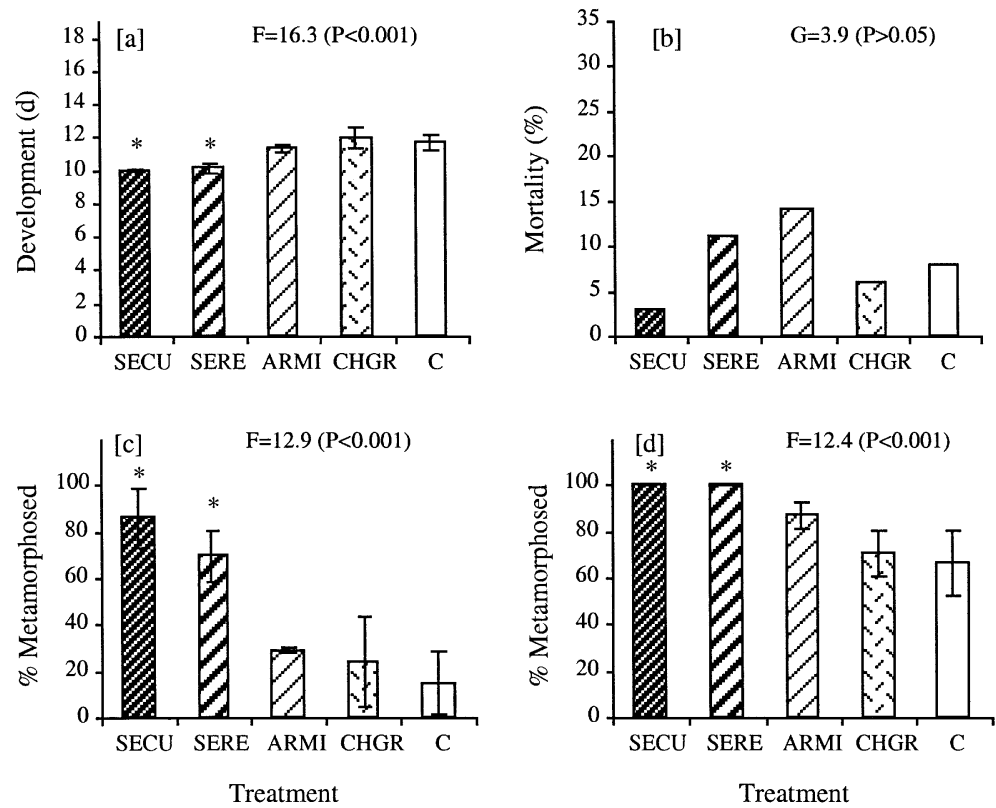

Fig. 2. Effects of adult-conditioned water with odors from conspecifics (S. curacaoense, SECU), a congener ( $S$. rectum, SERE), or other grapsid crab species (A. miersii, ARMI; C. granulata, CHGR) on the development and survival of $S$. curacaoense megalopae (experiment 2; female \#3). C: control group (filtered seawater, not conditioned with adults). (a) Duration of development (days) through the megalopa stage; range: $8-11$ days with $S$. curacaoense, 8-12 days with $S$. rectum, 10-16 days with A. miersii, 10-18 days with C. granulata ACW, $10-15$ days without substrate. (b) Mortality (\%). (c) Percentage of metamorphosed megalopae (means \pm S.D.) on the day when, in the treatment with the fastest development, at least $50 \%$ of the megalopae passed through metamorphosis (day 10). (d) Percentage of metamorphosed megalopae (means \pm S.D.) on the day when, in all treatments combined, at least $50 \%$ of the megalopae passed through metamorphosis (day 12 ). $H$ : Kruskal-Wallis statistic; $F$ : $F$-statistic; $G$ : statistic of $G$-test for independence; $P$ : probability of error for rejecting the null hypothesis. * Significant difference $(P<0.05)$ based on multiple comparisons. 
The mean duration of the megalopa stage was in both trials strongly affected by the presence or absence of conspecific adults $(P<0.0001$; Fig. 1a). With adult-conditioned water $(\mathrm{ACW})$, the average development time to metamorphosis was $8.8 \pm 0.8$ days vs. $13.0 \pm 1.4$ and $12.2 \pm 0.7$ days in the two control groups.

On day 8 , nearly $55 \%$ of the megalopae in the ACW treatment had undergone metamorphosis, while only $1 \%$ and $0 \%$, respectively, moulted by that time in the two control groups $(P<0.0001$; Fig. 1c). Three days later, more than $50 \%$ of the megalopae in all treatments reached metamorphosis to the first juvenile stage, but again with a significant difference between the ACW and the control groups $(P<0.001$; Fig. 1d). In this experiment, the rate of mortality was also affected by the presence of an adult $(P<0.05$; Fig. 1b), being lowest $(3.0 \%)$ in the treatment with ACW and significantly higher $(7-18.5 \%)$ in the controls with filtered seawater.

\subsection{Intra- and interspecific effects of adult odors (experiment 2)}

Under otherwise identical conditions, the development of megalopae obtained from the three different females (\#\# 3-5) showed significant intraspecific variability $(P<0.02$;
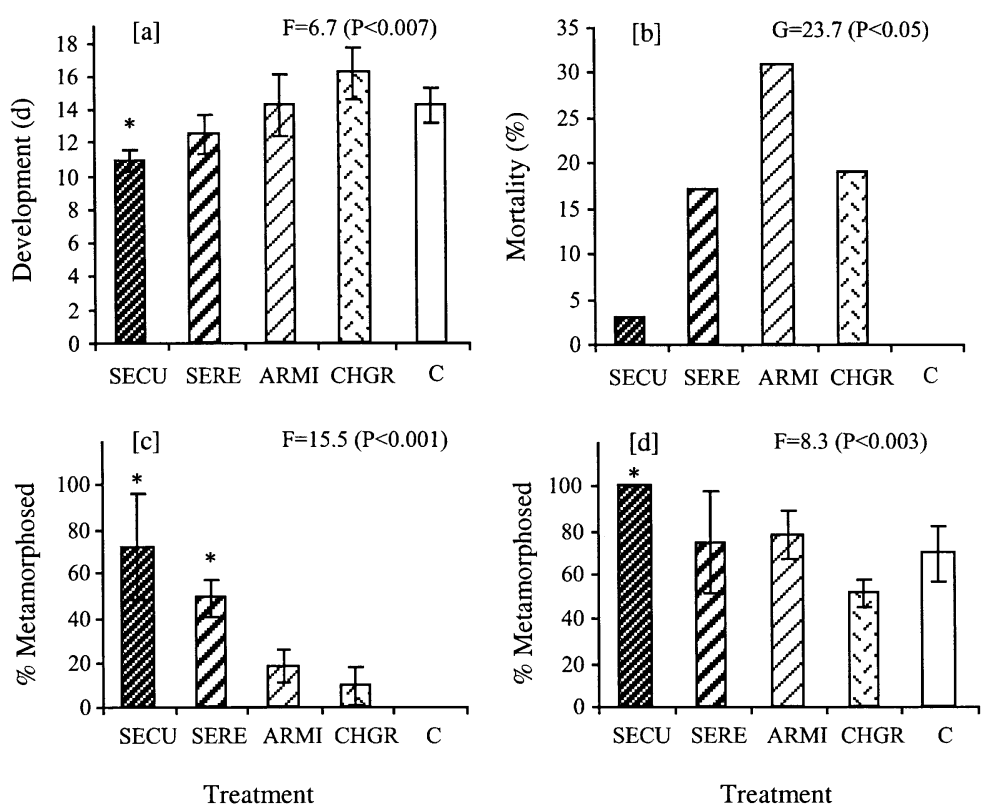

Fig. 3. Effects of adult-conditioned water with odors from conspecifics ( $S$. curacaoense, SECU), a congener ( $S$. rectum, SERE), or other grapsid crab species (A. miersii, ARMI; C. granulata, CHGR) on the development and survival of $S$. curacaoense megalopae (experiment 2; female \#4). C: control group (filtered seawater, not conditioned with adults); range of development duration: 9-12 days with $S$. curacaoense, 8-14 days with $S$. rectum, 10-31 days with $A$. miersii, 10-30 days with $C$. granulata ACW, 12-24 days without substrate. For further explanations, see Fig. 2. 
ANOVA). Therefore, the results for these three hatches were, in this series of experiments, not pooled but analysed separately. The mortality in the megalopa stage was generally very low in the treatment with conspecific ACW (consistently $<4 \%$ ), while mostly higher values were observed in the other treatments. However, the mortality figures did not show consistent patterns (Figs. 2-4b) and, thus, there was no significant relationship with the experimental conditions.

As in experiment 1, the mean development duration was significantly shorter, and the percentage of metamorphosed megalopae on two selected days of development was higher, when megalopae were reared in ACW as compared with those in filtered seawater $(P<0.01$, Figs. $2-4 \mathrm{a}, \mathrm{c}, \mathrm{d})$. In two out of three experimental sets (first and third trial), a significant effect on metamorphosis was observed not only in water conditioned with conspecific crabs, but also with congeneric (S. rectum) ACW (Figs. 2a and 4a). The same stimulating effect can be seen also in the second trial, but here, it was weaker and, also due to generally high mortality (cf. Figs. 2-4b), statistically not significant. The analysis of cumulative moulting frequencies for two different times within the period of megalopa development showed in all three trials a significant metamorphosis-stimulating effect of congeneric ( $S$. rectum) ACW (Figs. 2-4c,d).

Our results suggest that not only conspecifics and a congener, $S$. rectum, had a metamorphosis-stimulating effect on $S$. curacaoense megalopae, but maybe also other
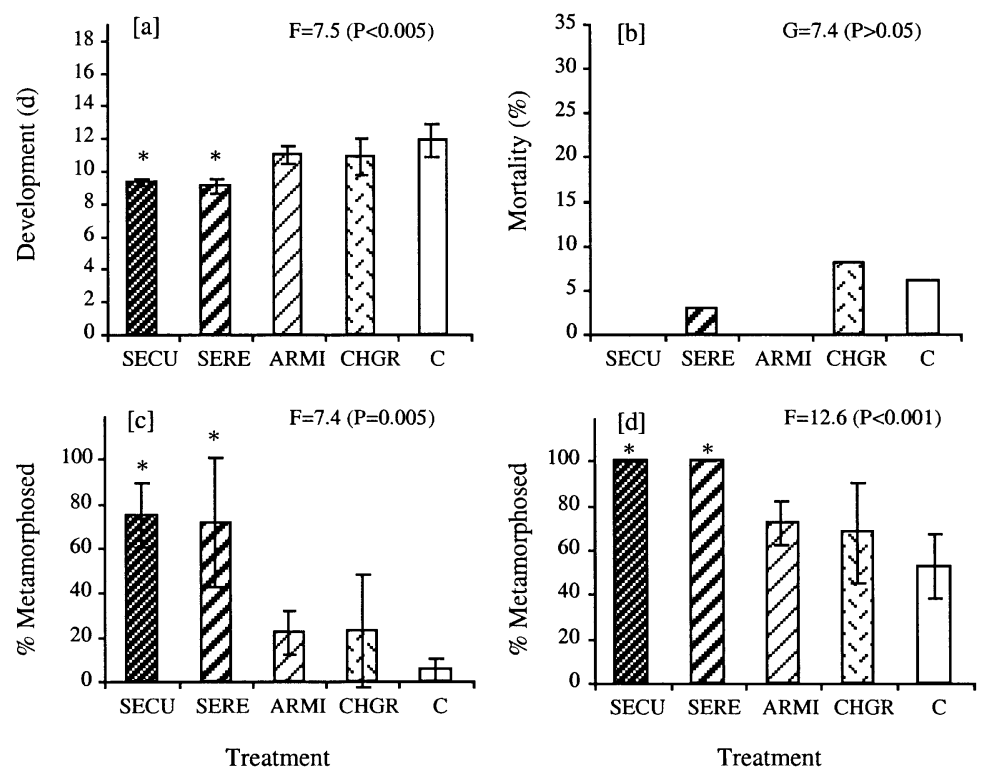

Fig. 4. Effects of adult-conditioned water with odors from conspecifics (S. curacaoense, SECU), a congener ( $S$. rectum, SERE), or other grapsid crab species (A. miersii, ARMI; C. granulata, CHGR) on the development and survival of $S$. curacaoense megalopae (experiment 2; female \#5). C: control group (filtered seawater, not conditioned with adults); range of development duration: 8-11 days with $S$. curacaoense, 8-11 days with $S$. rectum, 9-16 days with $A$. miersii, 8-16 days with $C$. granulata ACW, 8-19 days without substrate. For further explanations, see Fig. 2. 
grapsid species. The percentage metamorphosis values (especially those on the day when $50 \%$ in the fastest developing group had moulted to a juvenile) were, in most cases, higher in treatments with ACW from A. miersii and C. granulata than in the control groups (see Figs. $2-4 \mathrm{c}, \mathrm{d}$ ), and the average development durations tended to be shorter (Figs. 2-4a). The influence of these species, however, was weak or absent and statistically not significant.

\section{Discussion}

This study provides additional evidence that motile species such as decapod crustaceans may depend on the environmental cues for the induction of settlement and metamorphosis, similar to numerous sedentary forms (see Pechenik, 1990). Our experiments showed that the megalopa stage of the semiterrestrial grapsid crab species $S$. curacaoense is significantly prolonged and its mortality may be enhanced when stimulating mechanical and chemical cues are lacking.

The effect of nylon gauze as a substrate reflects an increasingly benthic behaviour of the megalopa, which can be observed, keeping hold on fixed filamentous or other suitable bottom structures. This behaviour may be associated with hiding from predators or, more likely, with the need to fix the body during ecdysis. In the experiments without a substrate, an enhanced mortality occurs during the metamorphic moult, due to unsuccessful attempts to pull the body entirely out of the old cuticle (personal observation).

In all five experiments with larvae originating from five different females, water-borne chemical cues from conspecific adult crabs consistently had a significant metamorphosisstimulating effect on $S$. curacaoense megalopae, and in three out of these five experiments also, the mortality rate was reduced in comparison with that in sibling larvae reared in filtered seawater (control treatments). Thus, there is a clear evidence for an intraspecifically effective cue, which should indicate that the megalopa has found a favourable site for settlement, metamorphosis, and probably, for successful further development and growth to the adult stage.

The experimental evidence for an effective, although weaker, stimulating cue released by $S$. rectum is similarly striking (Figs. 2-4). Although $S$. rectum is a congener, this clear response of the megalopae of $S$. curacaoense is remarkable insofar as $S$. rectum is an allopatric species which, in nature, is not encountered by $S$. curacaoense. S. rectum occurs on the northwestern coasts of continental South America, with a single record from the Lesser Antilles (Grenada; see Schubart et al., 1999), while $S$. curacaoense is a Caribbean species (Abele, 1992). Hence, S. curacaoense should not have evolved the capability to chemically recognize $S$. rectum in its habitat. Yet the existing, although weaker response of $S$. curacaoense megalopae to the presence of this species suggests that the signal (presumably a pheromone) released by adult $S$. rectum is chemically similar, but not identical, to that from $S$. curacaoense. Since $S$. rectum has also a similar ecology (living in brackish coastal mangrove swamps; for details see Gerlach, 1958; Fransozo and Hebling, 1986), we suggest that the megalopae of S. rectum should respond 
in a similar way to conspecific cues, and probably also to congeneric adult odors, for instance, from $S$. curacaoense. This hypothesis remains to be tested in the future experiments.

Although differences in the development duration of $S$. curacaoense megalopae were statistically not significant, we observed largely consistent patterns also in the response to the presence of other grapsid crabs (see Figs. 2-4a,c,d). In general, the metamorphosisstimulating effect tended to decrease with increasing phylogenetic distance (for phylogenetic relationships among the American grapsids, see Schubart et al., 2000). The response was maximum when conspecific adults ( $S$. curacaoense) were present, slightly weaker when the water was conditioned with a congener $(S$. rectum), and much weaker (statistically insignificant) in ACW of less closely related species (A. miersii, C. granulata). The consistency of this trend in several repeated experiments with larvae from different females suggests that all these Grapsidae may release species-specific substances (putative pheromones) which are perceived, and more or less responded to, by competent megalopae. According to the variation in the strength of this response, the chemical structure of these cues should be similar among close relatives. This implies a genetic basis of both the cue and the response to it, apparently reflecting phylogenetic relationships within a clade.

In our experiments, we did not measure the body mass of adult crabs that were used for the conditioning of water. However, we can say that the mass-specific effectiveness of stimulating cues was strongest in conspecific ACW, as $S$. curacaoense is clearly the smallest among the species studied here ( $<10$ - vs. $>20$-mm carapace size). If the massspecific metabolite production is similar among species, the $S$. curacaoense pheromone must have been far less concentrated in ACW than the substances released by other species, yet they were far more effective.

The chemical nature of metamorphosis-stimulating cues in the Decapoda remains unknown. Ammonium was repeatedly proposed as a possible trigger of metamorphosis in marine invertebrate larvae, for example, in the shrimp Penaeus monodon (Chen and Lin, 1992), but this can largely be excluded here as an effective agent, because this metabolite is produced by all species that we tested, so that it cannot explain the differential response of competent megalopae to odors from different species. Since ammonia is toxic, it may actually have negative rather than stimulating effects (see Forward et al., 1997b). More likely, the chemical communication substance released by conspecific and related adults might have a polypeptide or neurotransmitter-related structure, as observed in several other marine invertebrates (see Painter et al., 1998; Yamamoto et al., 1999; Browne et al., 1998; Browne and Zimmer, 2001).

Ephemeral pools within a mangrove swamp represent a highly unpredictable environment in terms of physico-chemical and nutritional conditions, and thus, must have selected for traits that increase the chances of survival and reproduction within such a habitat. Several adaptive traits have recently been described in S. curacaoense. These include a reduced time of exposure to unpredictable conditions due to an abbreviated larval development (Anger et al., 1995), reduced nutritional vulnerability due to facultative lecithotrophy (Anger, 1995), and larval euryhalinity due to an unusually early ontogenetic appearance of osmoregulatory functions (Anger and Charmantier, 2000). In mangrove crabs such as $S$. curacaoense and $S$. rectum, metamorphosis-stimulating cues should 
further increase the chance to encounter a suitable microhabitat, which is already inhabited by conspecifics and thus, may provide a certain guarantee for successful postsettlement growth and maturation. Since this mechanism should increase the rate of survival in settling recruits, it can be considered as another adaptive trait in this and other ecologically similar grapsid crab species.

\section{Acknowledgements}

The first author acknowledges a grant from the Biologische Anstalt Helgoland; the second author was funded by the Deutscher Akademischer Austauschdienst (DAAD), Bonn, Germany. The third author likes to thank Professor Dr. G.S. Moreira and the staff of the Centro de Biologia Marinha (São Sebastião, Brazil) for their kind hospitality and help in the collection and maintenance of $S$. rectum. [SS]

\section{References}

Abele, L.G., 1992. A review of the grapsid crab genus Sesarma (Crustacea: Decapoda: Grapsidae) in America, with the description of a new genus. Smithson. Contrib. Zool. 527, 1-60.

Anger, K., 1995. Starvation resistance in larvae of a semiterrestrial crab, Sesarma curacaoense (Decapoda: Grapsidae). J. Exp. Mar. Biol. Ecol. 187, 161-174.

Anger, K., 1996. Salinity tolerance of the larvae and first juveniles of a semiterrestrial grapsid crab, Armases miersii (Rathbun). J. Exp. Mar. Biol. Ecol. 202, 205-223.

Anger, K., Charmantier, G., 2000. Ontogeny of osmoregulation and salinity tolerance in a mangrove crab, Sesarma curacaoense (Decapoda: Grapsidae). J. Exp. Mar. Biol. Ecol. 251, 265-274.

Anger, K., Schultze, K., 1995. Elemental composition (CHN), growth, and exuvial loss in the larval stages of two semiterrestrial crabs, Sesarma curacaoense and Armases miersii (Decapoda: Grapsidae). Comp. Biochem. Physiol. 111A, 615-623.

Anger, K., Schreiber, D., Montú, M., 1995. Abbreviated larval development of Sesarma curacaoense (Rathbun, 1897) (Decapoda: Grapsidae) reared in the laboratory. Nauplius, Rio Grande (Brazil) 3, 127-154.

Brodie, R.J., 1999. Ontogeny of shell-related behaviors and transition to land in the terrestrial hermit crab Coenobita compressus H. Milne Edwards. J. Exp. Mar. Biol. Ecol. 241, 67-80.

Browne, K.A., Zimmer, R., 2001. Controlled field release of a waterborne chemical signal stimulates planktonic larvae to settle. Biol. Bull. 200, 87-91.

Browne, K.A., Tamburri, M.N., Zimmer-Faust, R.K., 1998. Modelling quantitative structure-activity relationships between animal behaviour and environmental signal molecules. J. Exp. Biol. 201, 245-258.

Chen, J.C., Lin, C.Y., 1992. Effects of ammonia on growth and molting of Penaeus monodon juveniles. Comp. Biochem. Physiol. 101C, 449-452.

Christy, J.H., 1989. Rapid development of megalopae of the fiddler crab Uca pugilator reared over sediment: implications for models of larval recruitment. Mar. Ecol. Prog. Ser. 57, 259-265.

Fitzgerald, T.P., Forward, R.B., Tankersley, R.A., 1998. Metamorphosis of the estuarine crab Rhithropanopeus harrisii: effect of water type and adult odor. Mar. Ecol. Prog. Ser. 165, 217-223.

Forward, R.B., DeVries, M.C., Rittschof, D., Frankel, D.A.Z., Bischoff, J.P., Fisher, C.M., Welch, J.M., 1996. Effects of environmental cues on metamorphosis of the blue crab Callinectes sapidus. Mar. Ecol. Prog. Ser. $131,165-177$.

Forward, R.B., Swanson, J., Tankersely, R.A., Welch, J.M., 1997a. Endogenous swimming rhythms of blue crab, Callinectes sapidus, megalopae: effects of offshore and estuarine cues. Mar. Biol. 127, 621-628.

Forward, R.B., Tankersley, R.A., Blondel, D., Rittschof, D., 1997b. Metamorphosis of the blue crab Callinectes sapidus: effects of humic acids and ammonium. Mar. Ecol. Prog. Ser. 157, 277-286. 
Fransozo, A., Hebling, N.J., 1986. Desenvolvimento larval de Sesarma (Holometopus) rectum Randall, 1840 (Decapoda, Grapsidae) em laboratório. Rev. Bras. Biol. 46, 353-364.

Gebauer, P., Walter, I., Anger, K., 1998. Effects of substratum and conspecific adults on the metamorphosis of Chasmagnathus granulata (Dana) (Decapoda: Grapsidae) megalopae. J. Exp. Mar. Biol. Ecol. 223, 185-198.

Gebauer, P., Paschke, K., Anger, K., 1999. Costs of delayed metamorphosis: reduced growth and survival in early juveniles of an estuarine grapsid crab, Chasmagnathus granulata. J. Exp. Mar. Biol. Ecol. 238, $271-281$.

Gerlach, S.A., 1958. Die Mangroveregion tropischer Küsten als Lebensraum. Z. Morphol. Oekol. Tiere 46, 636730.

Harms, J., 1992. Larval development and delayed metamorphosis in the hermit crab Clibanarius erythropus (Latreille) (Crustacea, Diogenidae). J. Exp. Mar. Biol. Ecol. 156, 151-160.

Harvey, A.W., 1996. Delayed metamorphosis in Florida hermit crabs: multiple cues and constraints (Crustacea: Decapoda: Paguridae and Diogenidae). Mar. Ecol. Prog. Ser. 141, 27-36.

Jensen, G.C., 1991. Competency, settling behavior, and postsettlement aggregation by porcelain crab megalopae (Anomura: Porcellanidae). J. Exp. Mar. Biol. Ecol. 153, 49-61.

O'Connor, N.J., 1991. Flexibility in timing of the metamorphic molt by fiddler crab megalopae Uca pugilator. Mar. Ecol. Prog. Ser. 68, 243-247.

O'Connor, N.J., Gregg, A.S., 1998. Influence of potential habitat cues on duration of the megalopal stage of the fiddler crab Uca pugnax. J. Crustacean Biol. 18, 700-709.

O’Connor, N.J., Judge, M.L., 1997. Flexibility in timing of molting of fiddler crab megalopae: evidence from in situ manipulation of cues. Mar. Ecol. Prog. Ser. 146, 55-60.

Painter, S.D., Clough, B., Garden, R.W., Sweedler, J.V., Nagle, G.T., 1998. Characterization of Aplysia attractin, the first water-borne peptide pheromone in invertebrates. Biol. Bull. 194, 120-131.

Pechenik, J.A., 1990. Delayed metamorphosis by larvae of benthic marine invertebrates: does it occur? Is there a price to pay? Ophelia 32, 63-94.

Schubart, C.D., Horst, D., Diesel, R., 1999. First record of Sesarma rectum Randall (Brachyura, Grapsidae, Sesarminae) from the Lesser Antilles. Crustaceana 72, 537-538.

Schubart, C.D., Cuesta, J.A., Diesel, R., Felder, D.L., 2000. Molecular phylogeny, taxonomy, and evolution of nonmarine lineages within the American grapsoid crabs (Crustacea: Brachyura). Mol. Phylogenet. Evol. 15, $179-190$.

Snedecor, G.W., Cochran, W.G., 1967. Statistical Methods. The Iowa State Univ. Press, Ames, USA.

Sokal, R.R., Rohlf, F.J., 1995. BiometryThe Principles and Practice of Statistics in Biological Research, 3rd edn. Freeman, San Francisco.

Spivak, E.D., Anger, K., Luppi, T., Bas, C., Ismael, D., 1994. Distribution and habitat preferences of two grapsid crab species in Mar Chiquita Lagoon (Province of Buenos Aires, Argentina). Helgol. Meeresunters. 48, 5978.

Weber, J.C., Epifanio, C.E., 1996. Response of mud crab (Panopeus herbstii) megalopae to cues from adult habitat. Mar. Biol. 126, 655-661.

Wolcott, D.L., de Vries, M.C., 1994. Offshore megalopae of Callinectes sapidus: depth of collection, molt stage and response to estuarine cues. Mar. Ecol. Prog. Ser. 109, 157-163.

Yamamoto, H., Shimizu, K., Tachibana, A., Fusetani, N., 1999. Roles of dopamine and serotonin in larval attachment of the barnacle, Balanus amphitrite. J. Exp. Zool. 284, 746-758. 